Marina Karaseva-Sentsova

\title{
PROGRESSIVE TAXATION IN RUSSIA (LEGAL ASPECT)
}

Currently the Russian economy goes through the third stage of the tax reform. The first stage took place during the period from 1991 to 1998 and meant the transition to the market taxation. The second stage was connected with the adoption of the Tax Code of the Russian Federation in 1998 and the further development of the Russian tax system. The present stage of tax reforming in Russia is calculated for the period from 2008 to 2010. It is not so powerful as the first two stages. A main objective of tax reforming during the modern period is the adaptation of the tax laws of Russia to world economic processes. ${ }^{1}$

The tax system of Russia is three-level, which is caused by the federal system of the Russian State. It includes federal, regional and local taxes and charges. From the point of view of construction of tax rates the Russian tax system includes proportional (flat), progressive and regressive taxation. The central element of the Russian tax system is flat taxation. The progressive and regressive taxation takes the subordinated position.

Now in the European economic and legal science the question about the advantages and disadvantages of progressive and flat taxation is rather debatable. As for the tax law theory, in the European countries the problem of adequate legal construction tools in the personal income tax as proportional tax is actual. In this respect the Russian experience may be an object of certain interest.

1. Since 2001 the personal income tax in Russia has been constructed on a proportional (flat) scale of taxation. Today this tax is federal and established in the Tax Code of the Russian Federation (chapter.23). Before 2001 the personal income tax in Russia was progressive. This means the tax rate increased if the income of the individual increased.

It is important to note that the transformation of the personal income tax in Russia from progressive to proportional had both social reasons and legal possibilities. In

1 "The Basic directions of a tax policy of the Russian Federation for 2008 - 2010". Approved at meeting of the Government of the Russian Federation on March, 2nd, 2007. 
other words, there were two factors, which allowed to transform the personal income tax in Russia. These were social and legal factors.

The social factor which resulted in the necessity for the transformation of the personal income tax from progressive to proportional was the fact that it was mainly paid by individuals with low salary. Accordingly, the only segment that "worked" was the bottom rates at the progressive scale of taxation. Those levels of population which received high incomes, in the conditions of transition economy attempted to avoid taxation. And it was possible for them because of the imperfection and inconsistency in tax laws as well as banking law, insurance law and other branches of the Russian legislation. In particular, the basic part of wages was paid without any documents, the employer developed different schemes of payment to the employee as a kind of insurance etc. As a result, the personal income tax turned regressive by 2000. In other words, the tax rate did not increase, and remained at the same level for the taxpayer with high income.

The legal factor which enabled to implement flat taxation in Russia resulted from the fact that the Russian Constitution and even the Tax Code of the Russian Federation did not set forth the principle of progressiveness of taxation. Thus, the Russian legislator in 2000 was legally free to change the progressive personal income tax into proportional. ${ }^{2}$

It is important to notice, that Constitutions of some countries of the European Union establish a principle of progressiveness in taxation. In Italy, according to article 53 (2) of the Constitution "the tax system has to conform to the principle of progression". In Spain, the principle of progressiveness is established in article 31 (1) of the Constitution: "Everyone shall contribute to the public expenditure in proportion to his financial means, through a just and progressive system of taxation based on principles of equality, which shall in no case be confiscatory in character". The Portuguese Constitution mentions the progressivity requirement with respect to the income tax. According to article 104 (1) "Personal income tax shall seek to reduce inequality and shall be a single, progressive tax that tares account of family needs and income". In France, the progressivity of taxation is considered consistent with the principle of equality before public charges and with the ability to pay rule (both principles are formally established in the French bloc de constitutionnalité).

It is necessary to note that modern discussions on the efficiency of flat taxation in the European Union have only rhetorical character. As for the desire to adopt a flat taxation in a number of the EU member-countries, their main problem would result from their legal systems. 
2. From the point of view of understanding the principle of progressiveness it is possible to assert that the personal income tax in Russia is not progressive. The basic rate of personal income tax is $13 \%$. It is applied to the salary of the taxpayer as a kind of his income, to incomes of copyrights, to lease income etc.

At the same time it is necessary to have in view, that the Russian personal income tax is progressive in another sense. This progressiveness can be formulated as follows: with the increase in the income the sum of the tax paid in the budget by the taxpayer also increases though the tax rate does not increase.

How is such progressiveness reached? There are two ways:

- the first way consists in standard tax deductions,

- the second way consists in the establishment of special, raised and lowered rates on separate types of income.

Standard tax deductions in Russia somewhat relieve the tax burden of the taxpayer with low income. Practically, the taxpayer with low income, using standard tax deductions, pays the personal income tax under the rate of $13 \%$.

The basic, most widespread standard tax deduction for the taxpayer today is 400 roubles every month (slightly more than 10 euros). It is used by the taxpayer until his income has exceeded 20,000 roubles. The indicated tax deduction expires on the month in which the income of the taxpayer exceeded 20,000 roubles. For example, if the employee monthly receives wages (income) in the sum of 10,000 roubles the tax deduction will be applied within two months i.e. until his income reaches 20,000 roubles. Accordingly, in these two months the person will pay the tax under the rate of $13 \%$ not from 10,000 roubles but from 9,600 roubles.

Besides, in the Tax Code of the Russian Federation (item 218) the tax deduction at the rate of 600 roubles monthly is provided. It acts until the income of the taxpayer has exceeded 40,000 roubles. This deduction concerns the taxpayer having children and extends on each child aged below 18 years. Besides, it holds in the case of the child being older yet below 24 and a student or a post-graduate student. This deduction supplies progressiveness of the personal income tax because actually it does not extend on the persons having the monthly income of 40,000 roubles and more.

The Tax Code of the Russian Federation provides other standard tax deduction. However, in our opinion, they cannot be considered as the deduction providing progressiveness of the personal income tax. The reason of this is that such deductions extend only on the persons having a certain social status (participants in the Great Patriotic War, people working at the liquidation of the Chernobyl accident etc.). Besides, these deductions are not limited. Thus, these deductions similarly can be 
used by both people with high and people with low income, having the corresponding social status.

It is clear that the above-mentioned standard tax deductions (400 and 600 rubles) hardly provide progressiveness of the income taxation since they are too small. Unfortunately, the Government of the Russian Federation does not provide any increase in the given tax deductions, which would be useful to maintain progressiveness in the personal income tax.

However, the Government of the Russian Federation is likely to enter into the concept of «indexed tax unit» in 2009. This unit will be applied to the various indicators established in money terms. Its purpose is to minimize inflationary effect, including that on tax laws. According to the "Basic directions of a tax policy in the Russian Federation for 2008-2010" it is proposed to establish the indexed tax unit to size tax deductions under the various taxes established in money terms. It is obvious, that this indexed tax unit will be also applied to standard tax deductions. That is why it will provide progressiveness in the personal income tax. It is interesting to note, that the above-mentioned tax unit will be annually established in the federal law on the federal budget for the next fiscal year.

As it has already been noted, the progressiveness of personal income tax in Russia is provided by special, raised and lowered rates on separate types of income.

Thus, according to item 224 of the Tax Code of the Russian Federation the tax rate of $35 \%$ is established for the following incomes:

- costs of any prizes and the prizes received as the result of competitions, games and other actions with the purposes of advertising goods, works and services, regarding excess of 4,000 roubles in the tax period;

- interest from bank investments. In this case the tax base is defined as the excess of the sum of the percent of interest from bank investments (according to the agreement between the bank and the individual) over the sum of interest, calculated according to the rate of the Central Bank of the Russian Federation). For example, the person has drawn 10,000 roubles according to the agreement on the bank deposit at the rate of $15 \%$. The rate of the Central Bank of the Russian Federation is $10 \%$. In this case the income of the taxpayer at the rate of the Central bank would make 6,667 roubles. Accordingly, the income exceeding the rate of Central Bank will make 3,333 roubles. That income (3,333 roubles) will be taxed at the rate of $35 \%$;

- the economy sums on percent if the taxpayer received a credit in the bank. In this case the tax base is defined as the excess of the sum of percentage towards the credit estimated proceeding from the three fourths of the current rate of the Central Bank of the Russian Federation over the sum of percent, 
estimated proceeding from the conditions of contract. For example, a person has drawn, under the agreement of the bank credit, 20,000 roubles with the credit rate of $2 \%$. The rate of the Central bank during the given period is $8 \%$. Three quarters of the rate of the Central Bank is $6 \%$. Consequently, the interest rate of the person who has drawn the credit below three quarters of the rate of the Central bank is $4 \%$ that makes 800 roubles. Proceeding from it, the taxpayer should pay the tax from 800 roubles under the rate of $35 \%$.

In the last two cases the raised tax rate (35\%) is established to preclude the taxpayer from avoidance of taxation if the employee receives wages in the form of bank contributions at high rate of interest and bank credits at the low interest due to the conspiracy with the employer.

The tax rate of $15 \%$ is established concerning the incomes which the taxpayer received in the form of dividends due to stockholding in the Russian enterprises. The taxpayer pays personal income tax at that rate if he is not a resident of the Russian Federation.

As a result of the above-mentioned conditions, the taxpayer having various incomes, i.e. incomes taxable at the rate of $13 \%$ and at the rate of $35 \%$, pays the personal income tax on the average at a higher rate than $13 \%$.

The lowered rate of the personal income tax is $9 \%$. It is applicable to the income in the form of dividend. The taxpayer pays the personal income tax at that rate if he is a tax resident of the Russian Federation.

As a result of the above-mentioned conditions the taxpayer having various incomes, i.e. incomes, taxable at the rate of $13 \%$ and at the rate of $9 \%$ pays the personal income tax on the average at a lower rate than $13 \%$.

Thus, it is possible to assert, that the personal income tax in Russia is not literally proportional. It is progressive, though also poorly progressive. Progression of another kind occurs in this case. In theory such progression is called as indirect progression.

In modern conditions the personal income tax in Russia provides rather essential revenues for the budget. Consequently, the Government of the Russian Federation is not liable to change the flat rate of the personal income tax into the progressive rate.

As a whole, it is necessary to note that in the Russian tax system there are no direct progressive taxes, i.e. taxes in classical understanding.

Perhaps, the individual property tax is close to a progressive tax in classical understanding. It is established in 1992 and now its reforming is expected. Since 
2009 the Government of the Russian Federation have been planning to replace this tax with the real estate tax.

Today the individual property tax can be considered as progressive because the tax rate grows along with the increasing in the cost of property. So, if the value of the property is below 300,000 roubles the tax rate amounts to $0,1 \%$; if the value of the property is from 300,000 roubles to 500,000 roubles the tax rate amounts from 0,1 to $0,3 \%$. If the value of property reaches over 500,000 roubles the tax rate extends from $0,3 \%$ to $2 \%$.

In 2009 this tax will be replaced by the real estate tax. The object of the real estate tax will be a uniform object: a real estate consisting of a land area and a residence. The Government of the Russian Federation plans to make this tax progressive. The tax rates will be established by local governments since the tax is local.

In summary, it is necessary to underscore, that the absence of direct progressive taxes in the Russian tax system by no means belittles the efficiency of this tax system. 


\section{Streszczenie}

Rosyjski system podatkowy charakteryzuje się trójpoziomowością, co jest spowodowane federalnym modelem. Składają się na niego podatki i opłaty federalne, regionalne oraz lokalne. Z punktu widzenia konstrukcji stawek podatkowych w rosyjskim systemie podatkowym funkcjonują stawki proporcjonalne (płaskie), progresywne i degresywne. Jednakże główne znaczenie posiada opodatkowanie proporcjonalne. Opodatkowanie progresywne i regresywne zajmują pozycję podrzędną.

Artykuł poświęcony został głównie podatkowi dochodowemu od osób fizycznych, który z zasady jest podatkiem proporcjonalnym, jednakże w jego konstrukcji występują takie elementy, które powodują, że pod wieloma względami posiada on cechy podatku progresywnego. 